\title{
Relation of the methylation state of RUNX3 and $p 16$ gene promoters with hepatocellular carcinoma in Egyptian patients
}

Fatma El-shaarawy', Mai M. Abo ElAzm², Rasha H. Mohamed³, Mohamed I. Radwan, Dina M. Abo-Elmatty ${ }^{5}$ and Eman T. Mehanna ${ }^{*^{*}}$ (D)

\begin{abstract}
Background: Hepatocellular carcinoma (HCC) is the most common primary hepatic malignancy of adults. RUNX3 and $p 16$ are tumor suppressor genes that may be inactivated by hypermethylation which is a key epigenetic mechanism that contributes to the initiation and progression of various types of human carcinomas including HCC. The aim of this study was to assess the association of hypermethylation of RUNX3 and $p 16$ gene promoters with the incidence of HCC in Egyptian patients. The study included 120 subjects: 30 HCC patients, 30 patients with hepatitis C virus (HCV) without cirrhosis, 30 cirrhotic patients, and 30 healthy volunteers. Methylation-specific polymerase chain reaction (PCR) was done for detection of hypermethylated $p 16$ and RUNX3. Serum levels of liver enzymes and albumin were detected spectrophotometrically and alpha fetoprotein (AFP) was measured in serum by ELISA.

Results: Methylation of RUNX3 and $p 16$ was detected in 25/30 (83.3\%) and 26/30 (86.7\%) of HCC patients, respectively. The methylation state of both RUNX3 and $p 16$ genes was significantly higher in HCC patients compared to the control subjects $(P=0.016, \mathrm{OR}=4.38)$ and $(P=0.014, \mathrm{OR}=4.97)$, respectively. The methylation of both promoters was associated with higher AFP levels in the serum of all patients.
\end{abstract}

Conclusions: Hypermethylation of RUNX3 and p16 is significantly associated with the development of HCC and may be implicated in its pathogenesis.

Keywords: RUNX3, p16, Hepatocellular carcinoma, Methylation, Alpha fetoprotein

\section{Background}

Liver cancer is ranked as the fifth most common malignancy and the second responsible cause of cancer-related death around the world. Hepatocellular carcinoma (HCC) accounts for about $90 \%$ of primary liver malignancies [1]. In Egypt, chronic hepatitis C virus (HCV) is a major health burden and a major risk factor for HCC [2].

Alteration of DNA methylation at promoter regions has a recognized role during early evolution and development of human diseases, including cancers. It can be in

\footnotetext{
*Correspondence: eman.taha@pharm.suez.edu.eg

${ }^{5}$ Department of Biochemistry, Faculty of Pharmacy, Suez Canal University,

Ismailia 41522, Egypt

Full list of author information is available at the end of the article
}

the form of hypermethylation, hypomethylation, or loss of imprinting [3]. This alteration causes inactivation of tumor suppressor genes and activation of oncogenes by genetic and epigenetic mechanisms responsible for carcinogenesis [4]. DNA methylation occurs mostly at the $5^{\prime}$ of cytosine in CpG dinucleotides which are found in promoter regions [5].

RUNX Family Transcription Factor 3 (RUNX3) encoding gene is a member of the runt domain- containing family of transcription factors and one of the most critical genes that play a crucial role in the regulation of cellular processes as proliferation, apoptosis, angiogenesis, cellular adhesion and invasion [6]. RUNX3 is located at chromosomal region $1 \mathrm{p} 36-35$, and is frequently deleted 
in different malignancies, such as colon, bladder, breast, lung, gastric, and liver cancers [7]. RUNX3 promoter methylation (hypermethylation) has been found to play a critical role in hepatic epithelial tumorigenesis and epithelial-mesenchymal transition of HCC and is suggested to be helpful as a biomarker for early diagnosis of $\mathrm{HCC}$ [8].

The p16 gene (known as cyclin-dependent kinase inhibitor 2A, CDKN2A) is a tumor suppressor gene, located on chromosome 9p21. It can inhibit the cyclindependent kinase $4(\mathrm{CDK} 4)$ /cyclin D complex activation in the G1 phase of the cell cycle by encoding the $p 16$ protein, which selectively deactivates CDK4 [9]. Lack of $p 16$ gene expression may result in uncontrolled cellular division. Several mechanisms of $p 16$ inactivation had been recognized such as point mutations, homozygous deletions, and promoter hypermethylation [10]. p16 hypermethylation may be involved in hepato-carcinogenesis from early stages and persistent hepatitis virus infection may play a role in the induction of $p 16$ promoter methylation in hepato-carcinogenesis [11].

Although previous studies have examined the role of $R U N X 3$ and $p 16$ gene promoters methylation in cancer progression, limited studies have assessed their role in HCC progression $[12,13]$ in Egypt and Arab countries. The aim of this study was to assess the state of hypermethylation of the RUNX3 and p16 gene promoters in Egyptian patients with HCC and other chronic liver diseases that are widely spread in Egypt as well (i.e. HCV and liver cirrhosis).

\section{Methods}

\section{Study participants}

The patients in this case control study were recruited from Tropical Medicine Department (outpatient, inpatient and ICU) at Zagazig University Hospital, Zagazig, Egypt. The study included 120 subjects divided into four groups (HCC, HCV without cirrhosis, HCV related cirrhosis, and apparently healthy controls) 30 subjects for each. The sample size required to investigate the association of RUNX3 and $p 16$ gene promoters hypermethylation with the incidence of HCC in the current study was calculated using the formula described by Charan and Biswas [14] with a power of $80 \%$ and a margin of error of 0.05 . HCC was diagnosed according to the criteria of the European Association for the Study of the Liver (EASL) $[15,16]$. The diagnosis of HCC was confirmed by pathological examination or elevation of alpha-fetoprotein (AFP) $>400 \mathrm{ng} / \mathrm{mL}$, combined with imaging examinations including magnetic resonance imaging (MRI) and/ or computerized tomography (CT) [17].

Patients were investigated for anti-HCV antibodies using second generation enzyme linked immunosorbent assay (ELISA), with polymerase chain reaction (PCR) for HCV RNA positivity. Diagnose of liver cirrhosis was confirmed by combined clinical, laboratory and radiological findings. A questionnaire regarding the medical history including age at exposure to the virus and drug history was obtained. Clinical signs of portal hypertension and liver cell failure were evaluated.

Subjects who had history of any other causes of hepatitis, e.g. hepatitis B virus (HBV) or HCV co-infection with HBV, as well as other liver disorders, e.g. alcoholic liver disease or drug-related liver disease, and other causes of liver cirrhosis were excluded. Written consent was obtained from all participants, and the current study was approved by the Ethics Committee of Faculty of Pharmacy, Suez Canal University (Code 201807RH4).

\section{Laboratory measurements}

Peripheral venous blood $(5 \mathrm{~mL})$ was drawn after a $10 \mathrm{~h}$ fast and a portion was collected with EDTA anticoagulant and used for DNA extraction. The serum was separated from the remaining portion of the blood samples by centrifugation at $3000 \mathrm{rpm}$ for $15 \mathrm{~min}$. and used for assessment of: alanine aminotransferase (ALT), aspartate aminotransferase (AST), and albumin spectrophotometrically (Spectrum, Egypt). AFP was assessed in the serum by Human alpha Fetoprotein ELISA Kit (Cat No. ab108838) (Abcam, UK).

\section{Analysis of the methylation state of RUNX3 and $p 16$ gene promoters}

Analysis of methylation status was carried out on DNA extracted from whole anticoagulated blood using Wizard genomic DNA purification kit (Cat No. A1120) (Promega, USA) according to the manufacturer's instructions. Purity and concentration of the isolated DNA were tested by NanoDrop ND-1000 spectrophotometer (Thermo Fisher Scientific, USA). Extracted DNA was stored at $-20{ }^{\circ} \mathrm{C}$. Genomic DNA (2 $\left.\mu \mathrm{g}\right)$ was subjected to bisulfite modification with EpiTect Bisulfite conversion kit (QIAGEN, Germany) according to the protocol recommended by the manufacturer.

For assessment of the methylation state of each of RUNX3 and $p 16$ genes, a $25 \mu \mathrm{L}$ PCR reaction was performed for each sample; containing approximately $100 \mathrm{ng}$ of the bisulfite modified DNA, $0.5 \mathrm{mM}$ of each of the sense and anti-sense primers, $200 \mu \mathrm{M}$ dNTPs, $1 \times$ PCR buffer, $1.5 \mathrm{mM} \mathrm{MgCl}_{2}$ and $1.25 \mathrm{U}$ of the HotStarTaq DNA polymerase (QIAGEN, Germany). The conditions of the amplification reactions were as follows: initial denaturation at $95{ }^{\circ} \mathrm{C}$ for $5 \mathrm{~min}$ followed by 35 cycles composed of: denaturation at $95^{\circ} \mathrm{C}$ for $30 \mathrm{~s}$, annealing for $30 \mathrm{~s}$, and extension at $72{ }^{\circ} \mathrm{C}$ for $30 \mathrm{~s}$, followed by a final extension at $72{ }^{\circ} \mathrm{C}$ for $4 \mathrm{~min}$. The primers and annealing temperatures 
specific for each of the methylated and unmethylated regions in both genes are presented in Table $1[18,19]$. The amplification products were separated on $2.5 \%$ agarose gel stained with ethidium bromide, and visualized with ultraviolet illumine. Completely methylated and unmethylated human genomic DNA were used as positive and negative controls, respectively (Epi Tect ${ }^{\circledR}$ PCR control DNA, QIAGEN, Germany).

\section{Statistical analysis}

Data were analyzed using the Statistical Package for Social Sciences (SPSS) version 20 (IBM, USA). For comparison between the four groups, data were presented as the means and standard deviation, one way analysis of variance (ANOVA) test followed by Tukey's

Table 1 The primer sequences and annealing temperatures applied in the PCR reactions

\begin{tabular}{|c|c|c|}
\hline Gene & Primers & $\begin{array}{l}\text { Annealing } \\
\text { temp }\left({ }^{\circ} \mathrm{C}\right)\end{array}$ \\
\hline \multicolumn{3}{|l|}{ RUNX3 } \\
\hline Methylated & $\begin{array}{l}\text { Sense: } \\
\text { 5'-TTACGAGGGGCGGTCGTACGCGGG-3' } \\
\text { Antisense: } \\
\text { 5'-AAAACGACCGACGCGAACGCCTCC-3' }\end{array}$ & 69.1 \\
\hline Unmethylated & $\begin{array}{l}\text { Sense: } \\
\text { 5'- TTATGAGGGGTGGTTGTATGTGGG-3' } \\
\text { Antisense: } \\
\text { 5'- AAAACAACCAACACAAACACCTCC-3' }\end{array}$ & 61.8 \\
\hline \multicolumn{3}{|l|}{ p16 } \\
\hline Methylated & $\begin{array}{l}\text { Sense: } \\
\text { 5'-TTATTAGAGGGTGGGGCGGATCGC-3' } \\
\text { Antisense: } \\
\text { 5'-GACCCCGAACCGCGACCGTAA-3' }\end{array}$ & 65 \\
\hline Unmethylated & $\begin{array}{l}\text { Sense: } \\
\text { 5'-TTATTAGAGGGTGGGGTGGATTGT-3' } \\
\text { Antisense: } \\
\text { 5'-CAACCCCAAACCACAACCATAA-3' }\end{array}$ & 60 \\
\hline
\end{tabular}

HSD post-hoc test for multiple comparisons was used. Qualitative data of methylation/unmethylation of gene promoters were represented by frequency and relative percentage and chi-square test was used for testing the association of the qualitative data. Values of age and biochemical parameters in patients with methylated and unmethylated promoters were presented as median and interquartile range (IQR) and compared by the MannWhitney $\mathrm{U}$ test. In all analyses, $P$ values $<0.05$ were considered statistically significant.

\section{Results}

General and biochemical parameters of the study groups are summarized in Table 2. Studied groups showed male percentage of $73.3 \%, 56.6 \%, 56.6 \%$ and $66.6 \%$ in healthy, $\mathrm{HCV}$, cirrhotic and HCC groups, respectively. Patients in the HCC group were significantly older than the control subjects, the HCV non-cirrhotic patients and the cirrhotic patients. Serum ALT levels were significantly increased in $\mathrm{HCV}$ patients compared to the control subjects $(P<0.001)$, whereas albumin levels were significantly lower in $\mathrm{HCV}$ patients than in the control group $(P<0.001)$. Liver cirrhosis patients and HCC patients showed significantly higher serum levels of ALT, AST, and AFP compared to both the control group and the HCV patients $(P<0.001)$. Consistently, levels of albumin in the serum were significantly decreased in both the cirrhotic and the HCC groups compared to the control subjects and the HCV patients $(P<0.001)$. Moreover, post-hoc test revealed a significant increase of serum AST levels in the HCC patients compared to liver cirrhosis patients $(P<0.001)$. AFP levels in HCC patients were markedly higher than its levels in all other groups $(P<0.001)$ (Table 2).

Table 3 shows that methylation of $R U N X 3$ promoter was detected in 16/30 (53.3\%) of the control subjects, 21/30 (70\%) of both HCV patients and liver cirrhosis

Table 2 General and biochemical parameters in the study groups

\begin{tabular}{|c|c|c|c|c|c|c|}
\hline & Control $(n=30)$ & $\mathrm{HCV}(n=30)$ & Cirrhosis $(n=30)$ & $\mathrm{HCC}(n=30)$ & $\mathrm{F}$ & $P$ value \\
\hline (Male/female) & $(22 / 8)$ & $(17 / 13)$ & $(17 / 13)$ & $(20 / 10)$ & & \\
\hline Age (years) & $48.10 \pm 6.67$ & $48.80 \pm 7.19$ & $50.50 \pm 4.24$ & $55.60 \pm 6.19^{* \#}$ & 8.490 & 0.0001 \\
\hline $\operatorname{ALT}(\mathrm{U} / \mathrm{L})$ & $27.09 \pm 2.05$ & $48.88 \pm 8.16^{*}$ & $61.95 \pm 9.82^{* \#}$ & $61.05 \pm 7.86^{* \#}$ & 149.389 & 0.0001 \\
\hline AST (U/L) & $23.08 \pm 3.14$ & $30.94 \pm 3.94$ & $63.28 \pm 15.46^{* \#}$ & $82.52 \pm 28.88^{* \# \$}$ & 100.277 & 0.0001 \\
\hline Albumin (g/dL) & $4.50 \pm 0.66$ & $3.07 \pm 0.52^{*}$ & $2.07 \pm 0.68^{* \#}$ & $1.61 \pm 0.71^{* \#}$ & 73.071 & 0.0001 \\
\hline $\operatorname{AFP}(\mathrm{ng} / \mathrm{mL})$ & $9.27 \pm 1.13$ & $13.13 \pm 3.62$ & $50.43 \pm 9.15^{* \#}$ & $483.72 \pm 91.24^{* \# \$}$ & 897.126 & 0.0001 \\
\hline
\end{tabular}

Data are expressed as mean \pm SD and analyzed using one-way ANOVA followed by Tukey's HSD post-hoc test

$H C V$ hepatitis $C$ virus, HCC hepatocellular carcinoma, $A L T$ alanine amino-transferase, AST aspartate amino-transferase, $A F P$ alpha fetoprotein

*Significantly different compared to the control subjects

\# Significantly different compared to the HCV non-cirrhosis patients

$\$$ Significantly different compared to the liver cirrhosis patients. Differences were considered significantly different at $P<0.05$ 
Table 3 Relation of methylation state of RUNX3 and p16 gene promoters with hepatitis C virus, liver cirrhosis, and hepatocellular carcinoma

\begin{tabular}{|c|c|c|c|c|c|c|}
\hline & \multicolumn{2}{|l|}{ RUNX3 } & \multirow[t]{2}{*}{$P$ value OR $(95 \% \mathrm{Cl})$} & \multicolumn{2}{|l|}{ p16 } & \multirow[t]{2}{*}{$P$ value OR $(95 \% \mathrm{Cl})$} \\
\hline & Methylated & Unmethylated & & Methylated & Unmethylated & \\
\hline Control $(n=30)$ & $16(53.3 \%)$ & $14(46.7 \%)$ & & $17(56.7 \%)$ & $13(43.3 \%)$ & \\
\hline $\mathrm{HCV}(n=30)$ & $21(70 \%)$ & $9(30 \%)$ & $\begin{array}{l}0.187 \\
2.04(0.71-5.89)\end{array}$ & $15(50 \%)$ & $15(50 \%)$ & $\begin{array}{l}0.605 \\
0.76(0.28-2.11)\end{array}$ \\
\hline Cirrhosis $(n=30)$ & $21(70 \%)$ & $9(30 \%)$ & $\begin{array}{l}0.187 \\
2.04(0.71-5.89)\end{array}$ & $23(76.7 \%)$ & 7 (23.3\%) & $\begin{array}{l}0.105 \\
2.51(0.83-7.64)\end{array}$ \\
\hline $\mathrm{HCC}(n=30)$ & $25(83.3 \%)$ & $5(16.7 \%)$ & $\begin{array}{l}0.016^{*} \\
4.38(1.32-14.50)\end{array}$ & $26(86.7 \%)$ & $4(13.3 \%)$ & $\begin{array}{l}0.014^{*} \\
4.97(1.39-17.82)\end{array}$ \\
\hline
\end{tabular}

Data are represented as $\mathrm{N}$ (\%). Comparisons were performed by chi-square test $H C V$ hepatitis $C$ virus, $H C C$ hepatocellular carcinoma, $O R$ odds ratio, $\mathrm{Cl}$ confidence intervals

*Indicates significant difference at $P<0.05$ compared to the control group

patients $(P=0.187, \mathrm{OR}=2.04)$ and in $25 / 30(83.3 \%)$ of HCC patients $(P=0.016, \mathrm{OR}=4.38)$. Methylation of $p 16$ promoter was also detected in $17 / 30(56.7 \%)$ of the control subjects, $15(50 \%)(P=0.605, \mathrm{OR}=0.76)$ of $\mathrm{HCV}$ non-cirrhotic patients, $23(76.7 \%)(P=0.105, \mathrm{OR}=2.51)$ of the liver cirrhosis patients, and in 26 (86.7\%) $(P=0.014, \mathrm{OR}=4.97)$ of $\mathrm{HCC}$ patients.

The relation of the methylation state of both RUNX3 and $p 16$ promoters with the biochemical hepatic markers in all 90 patients participating in the study was analyzed, where methylation of RUNX3 promoter was associated with significantly higher AFP levels $(P=0.044)$ (Fig. 1). Similarly, AFP and AST serum levels were significantly higher in patients who had methylated $p 16$ promoter $(P=0.015$ and $P=0.001$, respectively) (Fig. 2 ).

\section{Discussion}

The majority of $\mathrm{HCC}$ cases have a known underlying etiology. Chronic viral hepatitis (B and C) are the most common causes of HCC as they cause liver cirrhosis which is a major risk factor for HCC. In fact, all forms of cirrhosis may induce tumor formation, but patients with chronic viral hepatitis are at greater risk as one from every three patients with liver cirrhosis will complicate with HCC during lifetime [20].

Recently, the molecular genetics of HCC development have been researched extensively. Aberrant DNA cytosine methylation is one of these molecular genetics, which is consistent with epigenetic changes in human cancers. Generally, cancer cells have lower DNA methylation level than in normal cells. In contrast, some loci tend to show DNA hypermethylation in cancer cells [21, 22]. In HCC, CpG island hypermethylation is frequently recognized at the promoter region of critical tumor suppressor genes. For example, suppressor of cytokine signalling 1 (SOCS-1) was found to be deactivated in HCC cases because of promoter hypermethylation [23]. Methylation of several genes has also been found not only in HCC but also in its precursor conditions such as chronic hepatitis and liver cirrhosis, indicating that these lesions are early events in the evolution of this aggressive cancer [24]. The role of epigenetics changes in diagnosis and progression of diseases potentiates their use as novel biomarkers and therapeutic targets as well. The purpose of the current study was to assess the relation of the methylation state of the RUNX3 and $p 16$ gene promoters with chronic liver diseases in Egyptian patients.

The current study involved 90 chronic liver disease patients, including $\mathrm{HCV}$ but no cirrhotic, $\mathrm{HCV}$ related cirrhotic, and HCC patients. There was a significant correlation between age and incidence of HCC as age was significantly higher in HCC group in comparison to the control and HCV group. This matches with Fattovich et al. [25] who stated that older age at diagnosis is associated with increased incidence of HCC. The mean age of HCC group in the current study was 55.60 years in agreement with Shaker et al. [26] who found that the most frequent age category affected by HCC in Egypt was between 51 and 60 years. The current study found no relation of the age with $R U N X 3$ and $p 16$ promoter methylation in all patients (Figs. 1, 2).

In the current study, the percentage of males was higher than females in all groups especially in HCC group that included 20 males out of 30 patients (66.7\%). This agreed with El-Mougy et al. [27] who also detected male predominance among Egyptian HCC patients and explained it by the fact that DNA synthetic activities are usually higher in the cirrhotic tissue of the male than the female. Moreover, the high level of the estrogen metabolite 2-methoxyestradiol in females' liver apparently acts as a protective factor against HCC [28]. Darbari et al. [29] found that $\mathrm{HCC}$ occurs more frequently in men than in 
(A)

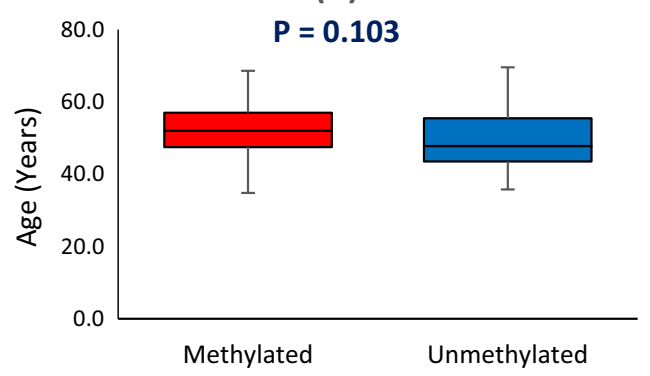

(C)

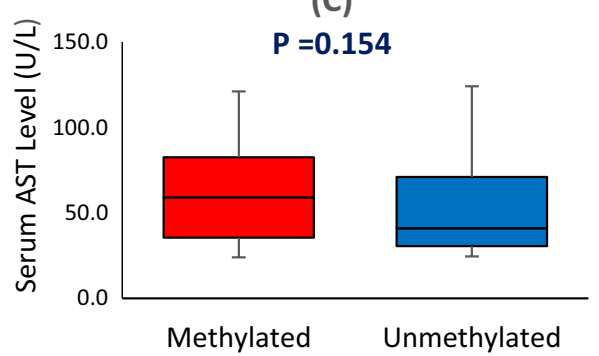

(B)

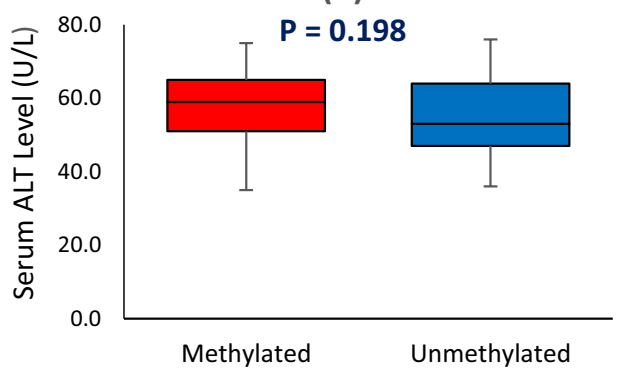

(D)

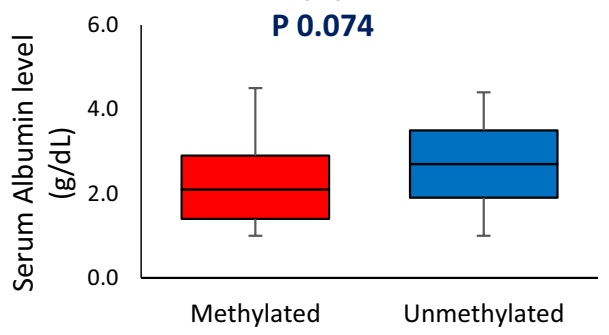

(E)

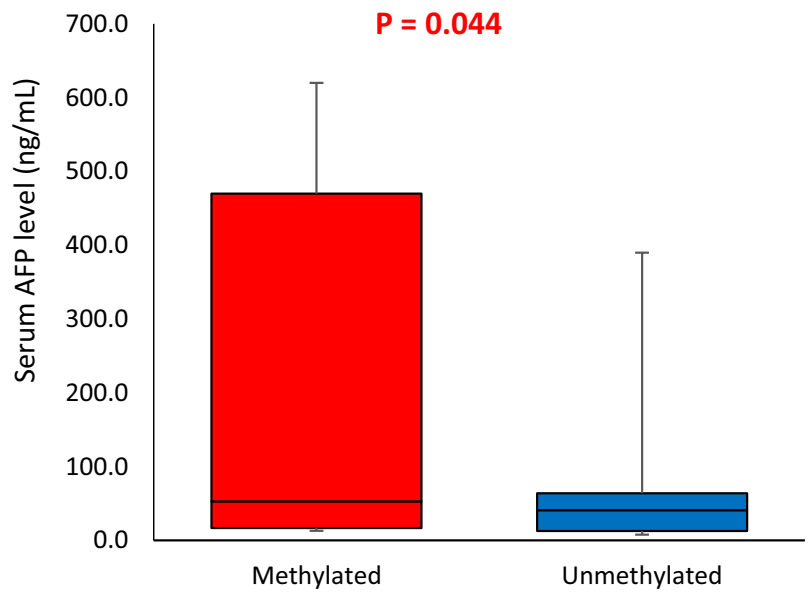

Fig. 1 Relation of RUNX3 promoter methylation with age and biochemical parameters in all participant patients. A Age, B serum ALT levels, C serum AST levels, D serum albumin levels, and $\mathbf{E}$ serum AFP levels. Data are represented as median and interquartile range; and compared by the MannWhitney $U$ test. The top, middle and bottom lines of the box plot indicate the 75th percentile, median and the 25th percentile values, respectively. Error bars demonstrate the maximal and minimal values. Differences were considered statistically significant at $P<0.05$

women, regardless of the geographic location with the male:female ratios may reach up to 5:1 in some countries.

Regarding ALT and AST liver enzymes there was a stepwise elevation in the means of both enzymes in all groups of patients (HCV, cirrhotic and HCC) as compared to the control group. This is explained by the chronic persistent and progressive damage of liver cells with presence $\mathrm{HCV}$ as an injurious agent. It induces both hepatic inflammation and fibrosis. HCV protein expression promotes the mutation and malignant transformation of the infected cells which is an important risk factor in developing HCC in Egypt [30]. Our results revealed significant decrease of serum albumin in cirrhosis and HCC patients in agreement with Seif et al. [13]. This can be attributed to the deterioration of liver synthetic function as cirrhosis progresses [31]. 
(A)

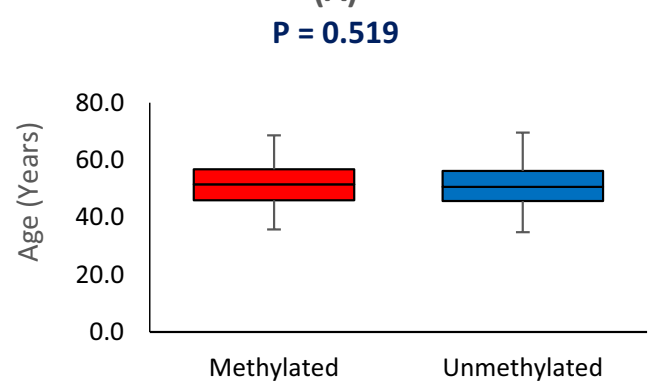

(C)

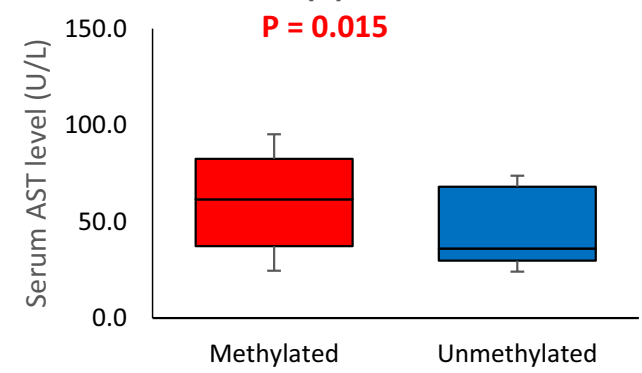

(B)

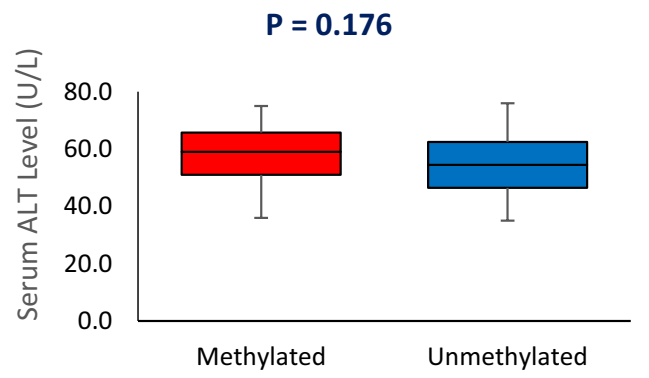

(D)

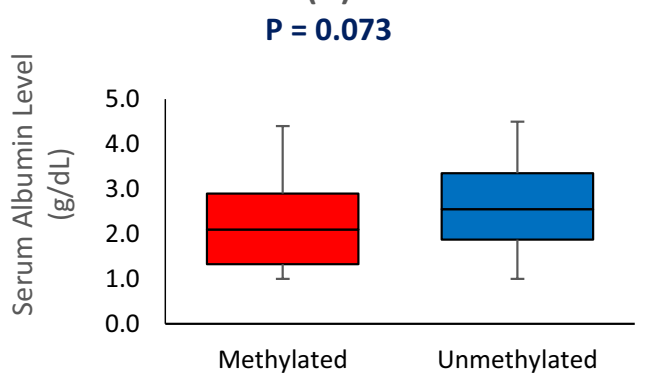

(E)

$P=0.001$

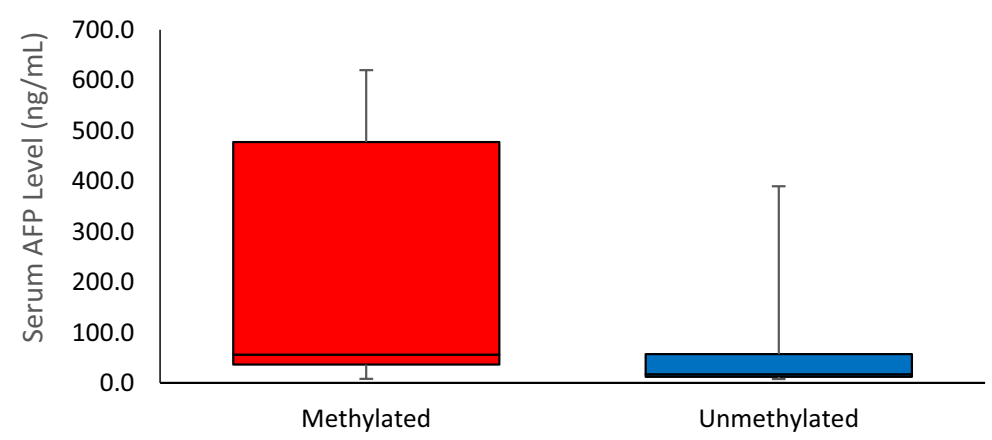

Fig. 2 Relation of p16 promoter methylation with age and biochemical parameters in all participant patients. A Age, B serum ALT levels, C serum AST levels, D serum albumin levels, and $\mathbf{E}$ serum AFP levels. Data are represented as median and interquartile range; and compared by the MannWhitney $U$ test. The top, middle and bottom lines of the box plot indicate the 75th percentile, median and the 25th percentile values, respectively. Error bars demonstrate the maximal and minimal values. Differences were considered statistically significant at $P<0.05$

Serum levels of AFP in this study were significantly increased in liver cirrhosis patients compared to both the control and HCV groups, but HCC patients had almost tenfold higher levels of AFP in comparison to the cirrhosis group. These findings are consistent with previous reports [12, 27]. AFP was first recognized as an HCC marker more than 40 years ago and has since been described to detect preclinical HCC [17]. In chronic liver disease, sustained increase in serum AFP was considered as one of the risk factors for HCC. In liver cirrhotic patients, increased serum AFP level may reflect sudden onset of viral hepatitis with deterioration of liver disease and HCC progression [32].

In the present study, $R U N X 3$ promotor methylation rate was significantly higher in HCC group relative to the control group [P value: 0.016 ; OR $(95 \% \mathrm{CI}): 4.38$ (1.32-14.50)]. Furthermore, RUNX3 hypermethylation was significantly correlated with higher serum levels of AFP in all patients. This confirms the suggestions that serum hypermethylation of $R U N X 3$ could be considered as a sensitive HCC marker [33] and may represent a new screening marker for liver cancer patients [34]. 
Earlier studies have revealed that RUNX family members play important roles in both normal developmental processes and carcinogenesis. RUNX3 inactivation by gene silencing via promoter hypermethylation is frequently involved in primary human gastric cancers [35]. A previous study reported that the methylation of six CpG loci in the RUNX3 gene was significantly different among HCC patients, high risk HCC patients, and healthy individuals, indicating that those RUNX3 gene loci might be involved in the epigenetic development of HCC. They suggested that, the abnormal methylation of RUNX3 in plasma may provide a new screening marker for HCC. However, the mentioned study found no significant correlation between the methylation of RUNX3 gene and the clinical feature of HCC patients [36]. Recently, in a study that involved 207 cases of HCV-related liver cirrhosis, 193 HCC patients and 53 healthy controls, methylation of RUNX3 was found to be significantly higher in the HCC group compared to both cirrhosis and healthy groups [12]. It was suggested that promoter hypermethylation of RUNX3 gene may be integrated in the early events of HCC development [37].

RUNX3 acts as a tumor suppressor and its inactivation can lead to tumor initiation and progression [38]. Decreased RUNX3 expression has been linked to cell cycle deregulation, inhibition of apoptosis and enhancement of angiogenesis [39]. RUNX3 is an important component of the transforming growth factor-beta signaling (TGF- $\beta$ ) pathway. RUNX3 is required for the TGF- $\beta$ mediated growth arrest, where it may be involved in induction of CDK inhibitors and/or the Smad-mediated repression of the proto-oncogene c-Myc promoter [40], by interacting with Smads through their C-terminal segment and recruiting Smads to subnuclear sites of active transcription to exert their biological control [41].

In the current study, $p 16$ promotor methylation was significantly higher in HCC group compared to the control group [ $P$ value: 0.014 ; OR $(95 \%$ CI) 4.97 (1.3917.82)]. Hypermethylation of $p 16$ was significantly associated with higher serum levels of AST and AFP in all patients. These data are in agreement with the findings of a recent study conducted on 30 adult patients with HCC versus 30 controls divided into 15 with liver cirrhosis and 15 healthy subjects, where $86.7 \%$ of HCC patients had aberrant methylation of $p 16$ gene. In 2017 a meta-analysis was done including collected studies on 3105 HCCs and 808 non-tumor controls (chronic hepatitis and liver cirrhosis), and found that $p 16$ promoter methylation was significantly higher in HCC than in non-HCC patients [42]. Therefore, aberrant $p 16$ methylation was suggested as an early diagnostic marker in blood of hepatocellular carcinoma patients [13].
Suggested explanations for aberrant $p 16$ methylation as a predisposing factor for $\mathrm{HCC}$ is that aberrant methylation of at least 1 cytosine can significantly inactivate p16 promoter with subsequent inhibition of its transcriptional activity. This happens due to alteration of the interaction between RNA helicase A enzyme, which facilitates the transcriptional function of the gene, and its regulatory region [4]. $p 16$ is a CDK inhibitor that plays a key role in cell cycle regulation [43]. The loss of $p 16$ expression through methylation has revealed its function as a tumor suppressor gene, suggesting frequent inactivation of this gene in human tumors [44]. As a tumor suppressor gene, the inactivation of $p 16$ gene results in excessive cell proliferation, accelerated cell cycles and a premature entry into the $S$ phase before DNA complete repair, resulting in tumorigenesis [45].

\section{Conclusions}

The current study reported a significant correlation of RUNX3 and p16 gene promoters' hypermethylation with $\mathrm{HCC}$ in Egyptian patients. Methylation of both genes was linked with increased AFP serum levels in chronic liver disease patients. The findings of the current study emphasize the previous reports of the association of $R U N X 3$ and $p 16$ gene promoters hypermethylation with HCC in different ethnicities; suggesting their potential viability as biomarkers for early detection of HCC. However, the findings of the current study are limited by the small sample size and the significant age difference between HCC patients and the control subjects.

\section{Abbreviations \\ AFP: Alpha fetoprotein; ALT: Alanine aminotransferase; AST: Aspartate aminotransferase; CDK4: Cyclin-dependent kinase 4; CT: Computerized tomography; EASL: European Association for the Study of the Liver; ELISA: Enzyme linked immunosorbent assay; HBV: Hepatitis B virus; HCC: Hepatocel- lular carcinoma; HCV: Hepatitis C virus; MRI: Magnetic resonance imaging; PCR: Polymerase chain reaction; RUNX3: Runt-related transcription factor 3; SOC-1: Suppressor of cytokine signalling 1; TNM: Tumor node metastasis; TGF- $\beta$ : Transforming growth factor-beta signaling.}

\section{Acknowledgements}

Not applicable.

\section{Authors' contributions}

FE substantively revised the manuscript. RHM and DMA designed the study. MIR collected the samples and was responsible for diagnosis of the cases. MMA and RHM performed the laboratory work. ETM performed the statistical analysis. MMA and ETM wrote the manuscript. All authors read and approved the final manuscript.

\section{Funding}

No funds, grants, or other support was received.

\section{Availability of data and materials}

The datasets used and/or analysed during the current study are available from the corresponding author on reasonable request. 


\section{Declarations}

\section{Ethics approval and consent to participate}

Written consent was obtained from all participants. The current study was conducted following the principles of Declaration of Helsinki, and approved by the Ethics Committee of Faculty of Pharmacy, Suez Canal University (Code 201807RH4).

\section{Consent for publication}

Not applicable.

\section{Competing interests}

He authors declare that they have no competing interests.

\section{Author details}

'Department of Biochemistry, Faculty of Pharmacy, Sinai University, Arish, North Sinai, Egypt. ${ }^{2}$ ElQanayat Hospital, Ministry of Health, Zagazig, Egypt. ${ }^{3}$ Department of Biochemistry, Faculty of Pharmacy, Zagazig University, Zagazig, Egypt. ${ }^{4}$ Department of Tropical Medicine, Faculty of Medicine, Zagazig University, Zagazig, Egypt. ${ }^{5}$ Department of Biochemistry, Faculty of Pharmacy, Suez Canal University, Ismailia 41522, Egypt.

Received: 15 June 2021 Accepted: 9 February 2022

Published online: 06 March 2022

\section{References}

1. Global Burden of Disease Liver Cancer Collaboration, Akinyemiju T, Abera S, Ahmed M, Alam N, Alemayohu MA, Allen C, Al-Raddadi R, Alvis-Guzman N, Amoako Y, Artaman A, Ayele TA, Barac A, Bensenor I, Berhane A, Bhutta Z, Castillo-Rivas J, Chitheer A, Choi JY, Cowie B, Dandona L, Dandona R, Dey S, Dicker D, Phuc H, Ekwueme DU, Zaki MS, Fischer F, Fürst T, Hancock J, Hay SI, Hotez P, Jee SH, Kasaeian A, Khader Y, Khang YH, Kumar A, Kutz M, Larson H, Lopez A, Lunevicius R, Malekzadeh R, McAlinden C, Meier T, Mendoza W, Mokdad A, Moradi-Lakeh M, Nagel G, Nguyen Q, Nguyen G, Ogbo F, Patton G, Pereira DM, Pourmalek F, Qorbani M, Radfar A, Roshandel G, Salomon JA, Sanabria J, Sartorius B, Satpathy M, Sawhney M, Sepanlou S, Shackelford K, Shore H, Sun J, Mengistu DT, Topór-Mądry R, Tran B, Ukwaja KN, Vlassov V, Vollset SE, Vos T, Wakayo T, Weiderpass E, Werdecker A, Yonemoto N, Younis M, Yu C, Zaidi Z, Zhu L, Murray CJL, Naghavi M, Fitzmaurice C (2017) The Burden of Primary Liver Cancer and underlying etiologies from 1990 to 2015 at the global, regional, and national level: results from the global burden of disease study 2015 . JAMA Oncol 3(12):1683-1691. https://doi.org/10.1001/jamaoncol.2017. 3055

2. Anwar WA, Khaled HM, Amra HA, El-Nezami H, Loffredo CA (2008) Changing pattern of hepatocellular carcinoma (HCC) and its risk factors in Egypt: possibilities for prevention. Mutat Res 659(1-2):176-184. https:// doi.org/10.1016/..mrrev.2008.01.005

3. Rosenbaum E, Begum S, Brait M, Zahurak M, Maldonado L, Mangold LA, Eisenberger MA, Epstein Jl, Partin AW, Sidransky D, Hoque MO (2012) AIM1 promoter hypermethylation as a predictor of decreased risk of recurrence following radical prostatectomy. Prostate 72(10):1133-1139. https://doi.org/10.1002/pros.22461

4. Shiraz OB, Galehdari H, Yavarian M, Geramizadeh B (2011) Possible down regulation of the p16 gene promoter in individuals with hepatocellular carcinoma. Hepat Mon 11(9):719-723. https://doi.org/10.5812/kowsar. $1735143 X .732$

5. Lim WJ, Kim KH, Kim JY, Jeong S, Kim N (2019) Identification of DNAmethylated $\mathrm{CpG}$ islands associated with gene silencing in the adult body tissues of the ogye chicken using RNA-seq and reduced representation bisulfite sequencing. Front Genet 10:346. https://doi.org/10.3389/fgene. 2019.00346

6. Subramaniam MM, Chan JY, Yeoh KG, QuekT, Ito K, Salto-Tellez M (2009) Molecular pathology of RUNX3 in human carcinogenesis. Biochim Biophys Acta 1796(2):315-331. https://doi.org/10.1016/j.bbcan.2009.07.004

7. Nomoto S, Haruki N, Tatematsu Y, Konishi H, Mitsudomi T, Takahashi T, Takahashi T (2000) Frequent allelic imbalance suggests involvement of a tumor suppressor gene at 1 p36 in the pathogenesis of human lung cancers. Genes Chromosomes Cancer 28(3):342-346. https://doi.org/10. 1002/1098-2264(200007)28:3\%3c342::aid-gcc13\%3e3.0.co;2-a

8. Yang Y, Ye Z, Zou Z, Xiao G, Luo G, Yang H (2014) Clinicopathological significance of RUNX3 gene hypermethylation in hepatocellular carcinoma. Tumour Biol 35(10):10333-10340. https://doi.org/10.1007/ s13277-014-2329-7

9. Rayess H, Wang MB, Srivatsan ES (2012) Cellular senescence and tumor suppressor gene p16. Int J Cancer 130(8):1715-1725. https://doi.org/10. 1002/ijc. 27316

10. Li J, Poi MJ, Tsai MD (2011) Regulatory mechanisms of tumor suppressor P16 (INK4A) and their relevance to cancer. Biochemistry 50(25):55665582. https://doi.org/10.1021/bi200642e

11. Tischoff I, Tannapfe A (2008) DNA methylation in hepatocellular carcinoma. World J Gastroenterol 14(11):1741-1748. https://doi.org/10.3748/ wjg.14.1741

12. El-Bendary M, Nour D, Arafa M, Neamatallah M (2020) Methylation of tumour suppressor genes RUNX3, RASSF1A and E-Cadherin in HCVrelated liver cirrhosis and hepatocellular carcinoma. Br J Biomed Sci 77(1):35-40. https://doi.org/10.1080/09674845.2019.1694123

13. Seif AA, Aly HH, Elzoghby DM, Elbreedy AM, Lotfy M (2019) Aberrant p16 methylation as an early diagnostic marker in blood of hepatocellular carcinoma patients. Egypt J Med Hum Genet 20:27. https://doi.org/10. 1186/s43042-019-0027-0

14. Charan J, Biswas T (2013) How to calculate sample size for different study designs in medical research? Indian J Psychol Med 35(2):121-126. https:// doi.org/10.4103/0253-7176.116232

15. Bruix J, Sherman M (2011) Management of hepatocellular carcinoma: an update. Hepatology 53(3):1020-1022. https://doi.org/10.1002/hep.24199

16. European Association for the Study of the Liver (2018) EASL Clinical practice guidelines: management of hepatocellular carcinoma. J Hepatol 69(1):182-236. https://doi.org/10.1016/j.jhep.2018.03.019

17. Bialecki ES, Di Bisceglie AM (2005) Diagnosis of hepatocellular carcinoma. HPB (Oxford) 7(1):26-34. https://doi.org/10.1080/13651820410024049

18. Herman JG, Graff JR, Myöhänen S, Nelkin BD, Baylin SB (1996) Methylation-specific PCR: a novel PCR assay for methylation status of $\mathrm{CpG}$ islands. Proc Natl Acad Sci U S A 93(18):9821-9826. https://doi.org/10.1073/pnas. 93.18.9821

19. Liu JB, Zhang YX, Zhou SH, Shi MX, Cai J, Liu Y, Chen KP, Qiang FL (2011) $\mathrm{CpG}$ island methylator phenotype in plasma is associated with hepatocellular carcinoma prognosis. World J Gastroenterol 17(42):4718-4724. https://doi.org/10.3748/wjg.v17.i42.4718

20. Ringelhan $M$, McKeating JA, Protzer U (2017) Viral hepatitis and liver cancer. Philos Trans R Soc Lond B Biol Sci 372(1732):20160274. https://doi. org/10.1098/rstb.2016.0274

21. Herceg Z, Hainaut P (2007) Genetic and epigenetic alterations as biomarkers for cancer detection, diagnosis and prognosis. Mol Oncol 1(1):26-41. https://doi.org/10.1016/j.molonc.2007.01.004

22. Liu M, Jiang L, Guan XY (2014) The genetic and epigenetic alterations in human hepatocellular carcinoma: a recent update. Protein Cell 5(9):673-691. https://doi.org/10.1007/s13238-014-0065-9

23. Yoshikawa H, Matsubara K, Qian GS, Jackson P, Groopman JD, Manning JE, Harris CC, Herman JG (2001) SOCS-1, a negative regulator of the JAK/STAT pathway, is silenced by methylation in human hepatocellular carcinoma and shows growth-suppression activity. Nat Genet 28(1):29-35. https:// doi.org/10.1038/ng0501-29

24. Chiba T, Yokosuka O, Fukai K, Hirasawa Y, Tada M, Mikata R, Imazeki F, Taniquchi H, Iwama A, Miyazaki M, Ochiai T, Saisho H (2005) Identification and investigation of methylated genes in hepatoma. Eur J Cancer 41 (8):1185-1194. https://doi.org/10.1016/j.ejca.2005.02.014

25. Fattovich G, Stroffolini T, Zagni I, Donato F (2004) Hepatocellular carcinoma in cirrhosis: incidence and risk factors. Gastroenterology $127(5$ Suppl 1):S35-50. https://doi.org/10.1053/j.gastro.2004.09.014

26. Shaker MK, Abdella HM, Khalifa MO, El Dorry AK (2013) Epidemiological characteristics of hepatocellular carcinoma in Egypt: a retrospective analysis of 1313 cases. Liver Int 33(10):1601-1606. https://doi.org/10. 1111/liv.12209

27. El-Mougy FA, Youssef MM, Omran DA, Sharaf SA, El-Sayed HH, Rabie WA, Mohamed EA, Elghobary HA (2014) Aberrant p16INK4A methylation: relation to viral related chronic liver disease and hepatocellular carcinoma. South Asian J Cancer 3(1):1-4. https://doi.org/10.4103/2278-330X.126498 
28. Teixeira AC, Mente ED, Cantao CAB, Sankarankutty AK, Souza FF, Motta TC, Monsignore L, Junior JE, Muglia VF, Abud DG, Peria FM, Silva OC, de Lourdes Candolo Martinelli A (2012) Clinical characteristics of 130 patients with hepatocellular carcinoma followed at a tertiary hospital from Brazil. World J Oncol 3(4):165-172. https://doi.org/10.4021/wjon5 $49 \mathrm{w}$

29. Darbari A, Sabin KM, Shapiro CN, Schwarz KB (2003) Epidemiology of primary hepatic malignancies in U.S. children. Hepatology 38(3):560-566. https://doi.org/10.1053/jhep.2003.50375

30. Ibrahim AS, Khaled HM, Mikhail NN, Baraka H, Kamel H (2014) Cancer incidence in Egypt: results of the national population-based cancer registry program. J Cancer Epidemiol 2014:437971. https://doi.org/10.1155/2014/ 437971

31. Balogh J, Victor D, Asham EH, Burroughs SG, Boktour M, Saharia A, Li X, Ghobrial RM, Monsour HP Jr (2016) Hepatocellular carcinoma: a review. J Hepatocell Carcinoma 3:41-53. https://doi.org/10.2147/JHC.S61146

32. Di Bisceglie AM, Sterling RK, Chung RT, Everhart JE, Dienstag JL, Bonkovsky HL, Wright EC, Everson GT, Lindsay KL, Lok ASF, Lee WM, Morgan TR, Ghany MG, Gretch DR, HALT-C Trial Group (2005) Serum alpha-fetoprotein levels in patients with advanced hepatitis C: results from the HALT-C trial. J Hepatol 43(3):434-441. https://doi.org/10.1016/j.jhep.2005.03.019

33. Tan SH, Ida H, Lau QC, Goh BC, Chieng W, Loh M, Ito Y (2007) Detection of promoter hypermethylation in serum samples of cancer patients by methylation-specific polymerase chain reaction for tumour suppressor genes including RUNX3. Oncol Rep 18:1225-1230. https://doi.org/10. 3892/or.18.5.1225

34. Sun G, Zhang C, Feng M, Liu W, Xie H, Qin Q, Zhao E, Wan L (2017) Methylation analysis of p16, SLIT2, SCARA5, and Runx3 genes in hepatocellular carcinoma. Medicine (Baltimore) 96(41):e8279. https://doi.org/10.1097/ MD.0000000000008279

35. Li QL, Ito K, Sakakura C, Fukamachi H, Ki Inoue, Chi XZ, Lee KY, Nomura S, Lee CW, Han SB, Kim HM, Kim WJ, Yamamoto H, Yamashita N, Yano T, Ikeda T, Itohara S, Inazawa J, Abe T, Hagiwara A, Yamagishi H, Ooe A, Kaneda A, Sugimura T, Ushijima T, Bae SC, Ito Y (2002) Causal relationship between the loss of RUNX3 expression and gastric cancer. Cell 109(1):113-124. https://doi.org/10.1016/s0092-8674(02)00690-6

36. Sun G, Zhang C, Feng M, Liu W, Xie H, Qin Q, Zhao E, Wan L (2017) Methylation analysis of p16, SLIT2, SCARA5, and Runx3 genes in hepatocellular carcinoma. Medicine (Baltimore) 96(41):e8279. https://doi.org/10.1097/ MD.0000000000008279

37. Park WS, Cho YG, Kim CJ, Song JH, Lee YS, Kim SY, Nam SW, Lee SH, Yoo NJ, Lee JY (2005) Hypermethylation of the RUNX3 gene in hepatocellular carcinoma. Exp Mol Med 37(4):276-281. https://doi.org/10.1038/emm. 2005.37

38. Lee SH, Bae SC, Kim KW, Lee YM (2014) RUNX3 inhibits hypoxia-inducible factor-1a protein stability by interacting with prolyl hydroxylases in gastric cancer cells. Oncogene 33(11):1458-1467. https://doi.org/10.1038/ onc.2013.76

39. Wu HC, Wang Q, Yang HI, Tsai WY, Chen C, Santella RM (2012) Global DNA methylation levels in white blood cells as a biomarker for hepatocellular carcinoma risk: a nested case-control study. Carcinogenesis 33:1340 1345. https://doi.org/10.1093/carcin/bgs160

40. Bae SC, Choi JK (2004) Tumor suppressor activity of RUNX3. Oncogene 23:4336-4340. https://doi.org/10.1038/sj.onc.1207286

41. Zaidi SK, Sullivan AJ, Wijnen AJV, Stein JL, Stein GS, Lian JB (2002) Integration of Runx and Smad regulatory signals at transcriptionally active subnuclear sites. Proc Natl Acad Sci USA 99:8048-8053. https://doi.org/ 10.1073/pnas.112664499

42. Lv X, Ye G, Zhang X, Huang T (2017) p16 Methylation was associated with the development, age, hepatic viruses infection of hepatocellular carcinoma, and p16 expression had a poor survival: a systematic meta-analysis (PRISMA). Medicine (Baltimore) 96(38):e8106. https://doi.org/10.1097/MD. 0000000000008106

43. Piepkorn M (2000) Melanoma genetics: an update with focus on the CDKN2A (p16)/ARF tumor suppressors. J Am Acad Dermatol 42(5 pt 1):705-722. https://doi.org/10.1067/mjd.2000.104687

44. Indovina P, Acquaviva A, De Falco G, Rizzo V, Onnis A, Luzzi A, Giorgi F, Hadjistilianou T, Toti P, Tomei V, Pentimalli F, Carugi A, Giordano A (2010) Downregulation and aberrant promoter methylation of p16INK4A: a possible novel heritable susceptibility marker to retinoblastoma. J Cell Physiol 223(1):143-150. https://doi.org/10.1002/jcp.22019
45. Qu Z, Jiang Y, Li H, Yu DC, Ding YT (2015) Detecting abnormal methylation of tumor suppressor genes GSTP1, P16, RIZ1, and RASSF1A in hepatocellular carcinoma and its clinical significance. Oncol Lett 10(4):2553-2558. https://doi.org/10.3892/ol.2015.3536

\section{Publisher's Note}

Springer Nature remains neutral with regard to jurisdictional claims in published maps and institutional affiliations.

\section{Submit your manuscript to a SpringerOpen ${ }^{\circ}$ journal and benefit from:}

- Convenient online submission

- Rigorous peer review

- Open access: articles freely available online

- High visibility within the field

- Retaining the copyright to your article

Submit your next manuscript at $\boldsymbol{\nabla}$ springeropen.com 